\title{
Status of the Herpetofauna in the Cauvery Delta Region, Mannampandal, Tamil Nadu, India
}

\author{
Pandi Karthik \\ Department of Zoology \& Division of Wildlife Biology, Anbhanathapuram Vahaira Charity College (autonomous), \\ Mannampandal, India (karthikwildlifebiology@gmail.com)
}

Tndia has a rich herpetofaunal diversity comprising 518 species of reptiles (Aengals et al. 2011) and 384 species of amphibians (Dinesh et al. 2013, 2015). India has two biogeographic hotspots, the Western Ghats and the Eastern Himalayas (Meyers et al. 2000). Comparatively more work (e.g., taxonomy, phylogeny, community ecology, and biogeography) has been conducted in the Western Ghats than in the Eastern Himalayas. However, apart from these hotspots, many other landscapes harbor unique assemblages of amphibians and reptiles, yet they remain relatively unexplored. Current knowledge of species richness and diversity in local areas is critically important when undertaking conservation measures. Considering the number of studies that have been carried out in other areas, especially the Western Ghats, data on the herpetofaunal community along the Coromandel Coast is very scarce (Ganesh and Chandramouli 2007, 2010; Nath et al. 2012). The unique scrub vegetation along the eastern Coromandel Coast provides habitat for a recentlydocumented rich herpetofaunal diversity that includes thirtyfive species of amphibians and reptiles. However, this region supports a dense human population, mainly associated with agricultural activities, which impose severe anthropogenic pressures on the natural biotic communities.

\section{Methods}

The study was carried out at Mannampandal $\left(11^{\circ} 6.354^{\prime} \mathrm{N}\right.$, $\left.79^{\circ} 41.584^{\prime} \mathrm{E}\right)$ in the Cauvery Delta region located in the

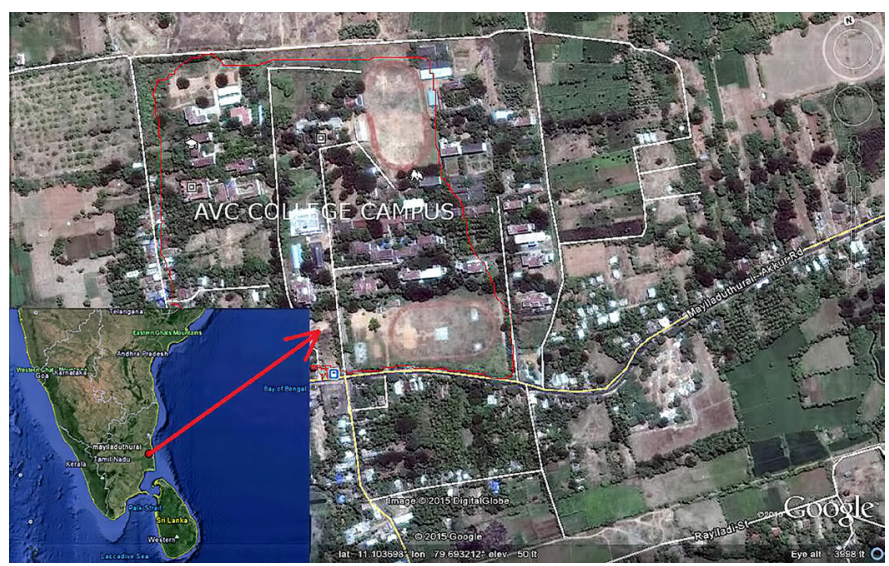

Fig. 1. Map of the study area in Mannampandal, Tamil Nadu, India.
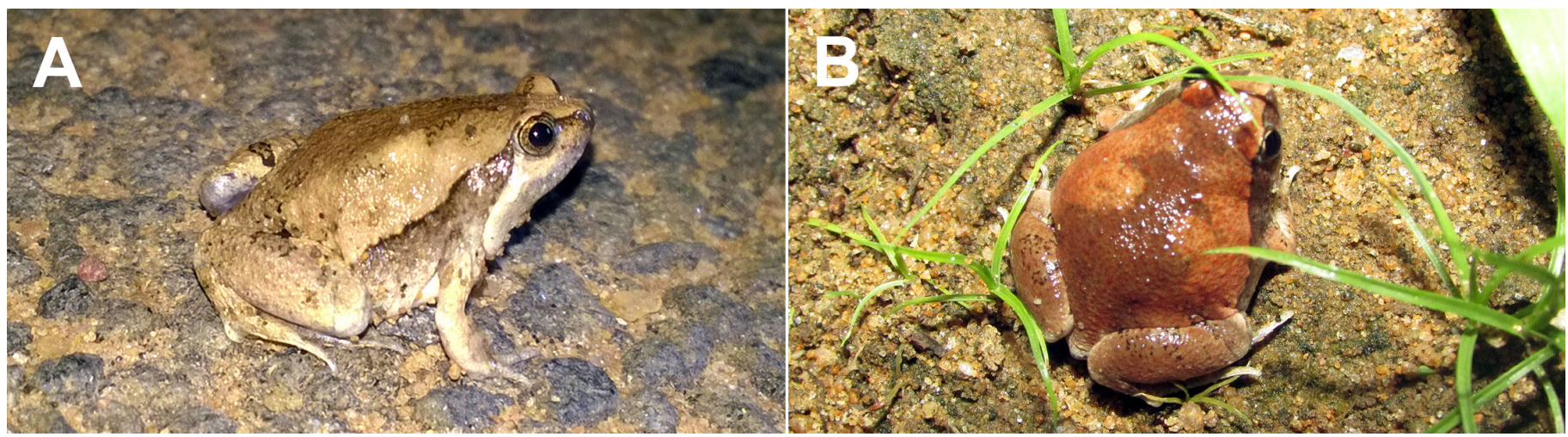

Fig. 2. Amphibians encountered during field surveys at Mannampandal in the Cauvery Delta, Nagapattinam District, Tamil Nadu, India: (A) Ornate Narrow-mouthed Frog (Microhyla ornata) and (B) Red Narrow-mouthed Frog (Microhyla rubra). 
Nagapattinam District of Tamil Nadu, India (Fig. 1). The vegetation is comprised mainly of sparsely distributed scrubs interspersed with trees, including Cocos nucifera, Borassusfla bellifer, Madhuca indica, Mangifera indica, Enterolobium saman, and Tamarindus indicus (Ali et al. 2011; Nath et al. 2012). The study area receives an annual precipitation of around $100 \mathrm{~cm}$, mainly from the northeastern monsoons.

Using the visual-encounter method (Heyer et al. 1994), I conducted field surveys in a variety of microhabitats (e.g., grassy areas, leaf litter, logs, along bodies of water, rock crev- ices, vegetation, road edges) in and around Mannampandal from July 2015 to October 2015. I also monitored the total number of snake rescues, which can be used as a measure of the anthropogenic pressure. Most surveys were conducted from 1700 h to $1900 \mathrm{~h}$, but I also carried out a few opportunistic surveys during the day. I identified species visually using published descriptions (Smith 1935; Daniel 2002; Whitaker and Captain 2004) and calculated their relative abundance. I analyzed data using Past 3.5 (Hammer 2017) and Microsoft Office 2010.

Table 1. Amphibians and reptiles encountered during field surveys in the Cauvery Delta Region, Mannampandal, Tamil Nadu, India. International Union for Conservation of Nature (IUCN) Red List status: LC = Least Concern; NE = Not Evaluated.

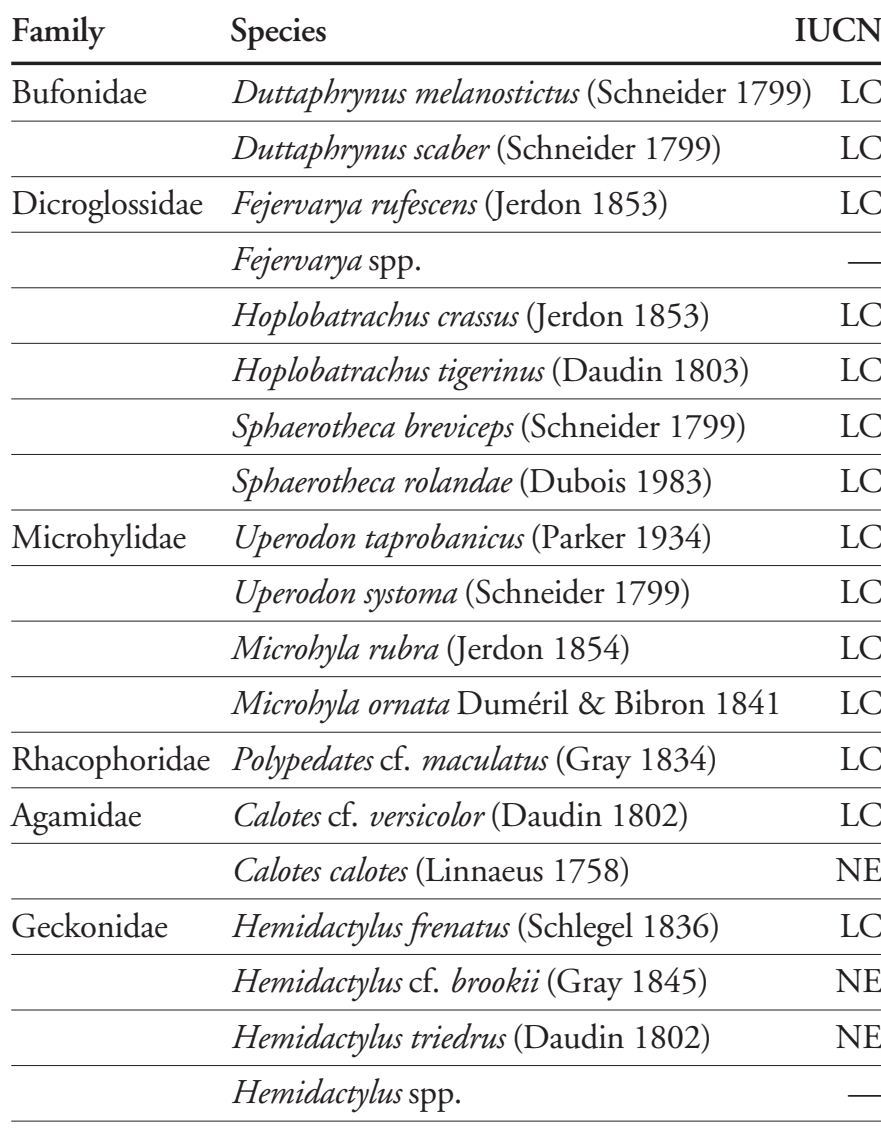

\begin{tabular}{llr} 
Family & Species & IUCN \\
\hline Scinicidae & Eutropis carinata (Schneider 1801) & LC \\
\hline Varanidae & Varanus bengalensis (Daudin 1802) & LC \\
\hline Colubridae & Ahaetulla cf. nasuta Lacépède 1789 & NE \\
\hline & Coelognathus h. helena (Daudin 1803) & NE \\
\hline & Dendrelaphis tristis (Daudin 1803) & NE \\
\hline & Dryocalamus nympha (Daudin 1803) & NE \\
\hline & Lycodon aulicus (Linnaeus 1758) & NE \\
\hline & Oligodon arnensis (Shaw 1802) & NE \\
\hline & Oligodon taeniolatus (Jerdon 1853) & LC \\
\hline Elapidae & Ptyas mucosa (Linnaeus 1758) & NE \\
\hline Bungarous caeruleus (Schneider 1801) & LC \\
\hline Natricidae & Naja n. naja (Linnaeus 1758) & NE \\
\hline & Amphiesma stolatum (Linnaeus 1758) & NE \\
\hline Typhlophidae & Indotyphlops braminus (Daudin 1803) & NE \\
\hline Viperidae & Daboia russelii (Shaw \& Nodder 1797) & NE \\
\hline
\end{tabular}
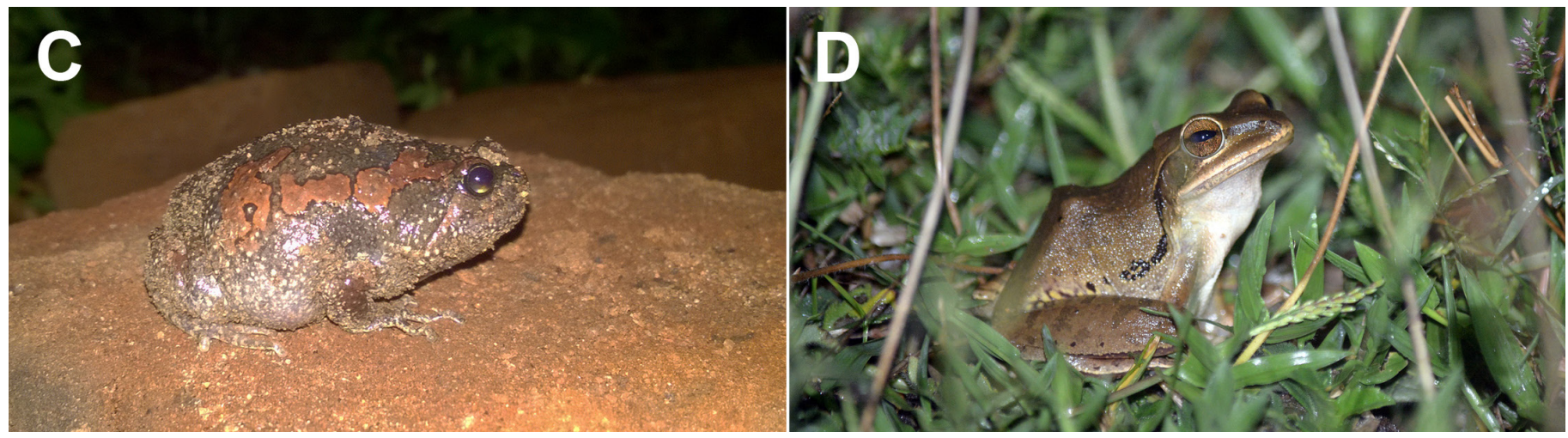

Fig. 3. Amphibians encountered during field surveys at Mannampandal in the Cauvery Delta, Nagapattinam District, Tamil Nadu, India: (C) Sri Lankan Bullfrog (Uperodon taprobanicus) and (D) Common Indian Treefrog (Polypedates cf. maculatus). 


\section{Results}

I encountered 230 individuals of 35 species (13 species of amphibians and 22 species of reptiles; Table1; Figs. 2-5) and calculated a Shannon Diversity Index $(\mathrm{H})$ of 1.52 . The rank abundance plot (Fig. 6) shows an alarming degree of rarity, as species numbered 18-34 on the graph were sighted only once during the surveys. Figures $7 \& 8$ clearly show that animals were rarely encountered on road edges and most frequently in association with bare ground, bodies of water, and human habitats.

Fifty-three snakes (nine species) were rescued from human habitations between November 2014 and November
2015 (Fig. 9). The most frequently encountered species were Indian Cobras (Naja naja) and Oriental Ratsnakes (Ptyas mucosa). Sixty-eight percent of snake rescues were successful (Fig. 10), 29\% of attempted rescues failed (no snakes were apprehended), and in $6 \%$ of rescues, snakes were killed by local people before rescuers arrived.

\section{Discussion}

Although I encountered 13 species of amphibians in four families and 22 species of reptiles in nine families, the Shannon Diversity Index of 1.52 indicated that the area has a relatively
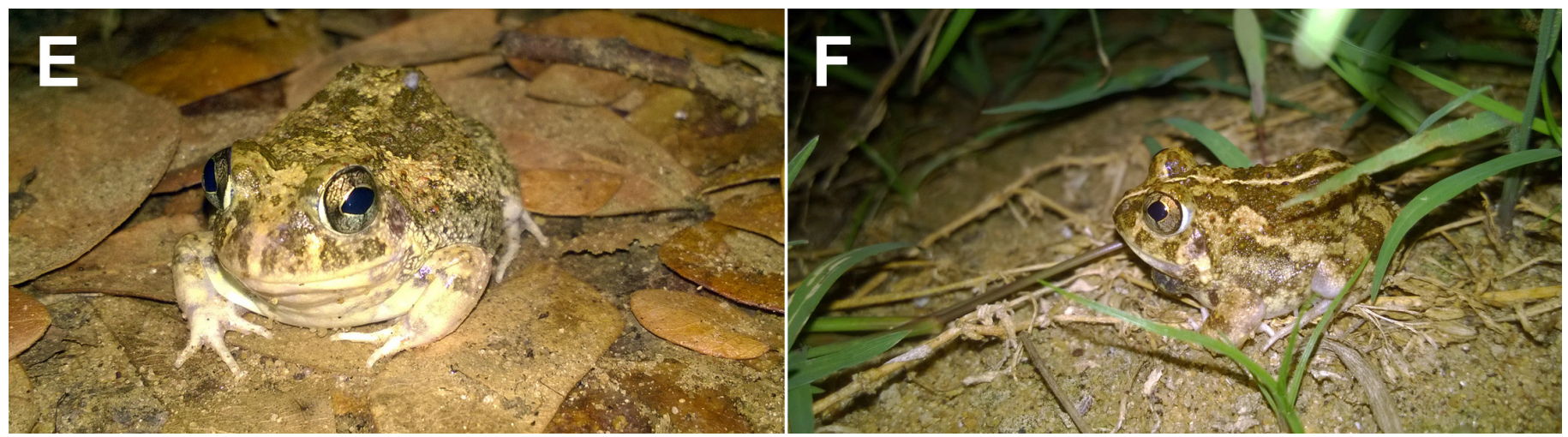

Fig. 4. Amphibians encountered during field surveys at Mannampandal in the Cauvery Delta, Nagapattinam District, Tamil Nadu, India: (E) Indian Burrowing Frog (Sphaerotheca breviceps) and (F) Roland's Burrowing Frog (Sphaerotheca rolandae).
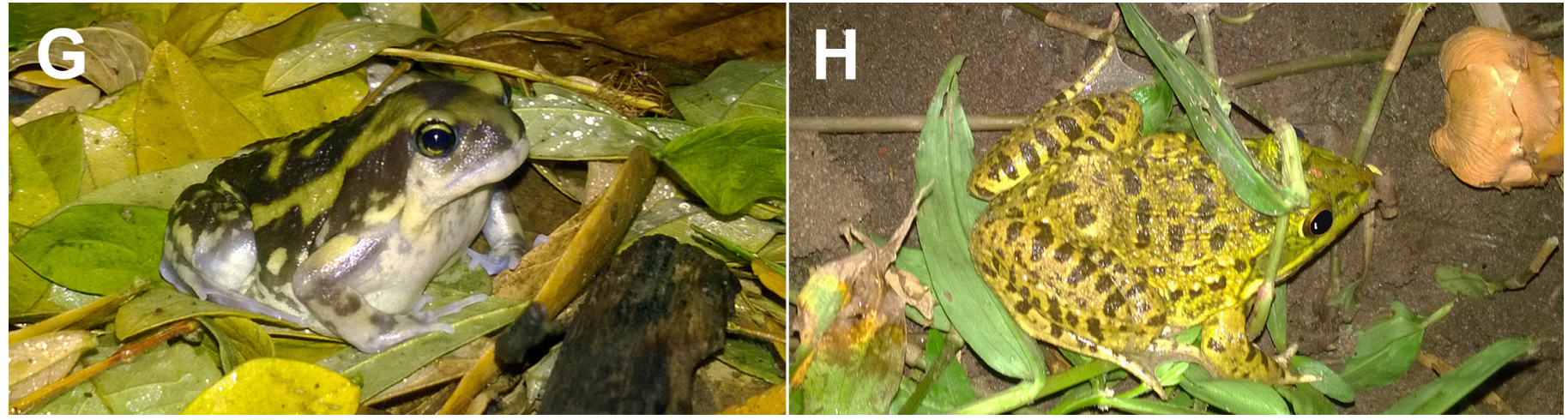

Fig. 5. Amphibians encountered during field surveys at Mannampandal in the Cauvery Delta, Nagapattinam District, Tamil Nadu, India: (G) Marbled Balloon Frog (Uperodon systoma) and (H) Jerdon's Bullfrog (Hoplobatrachus crassus).
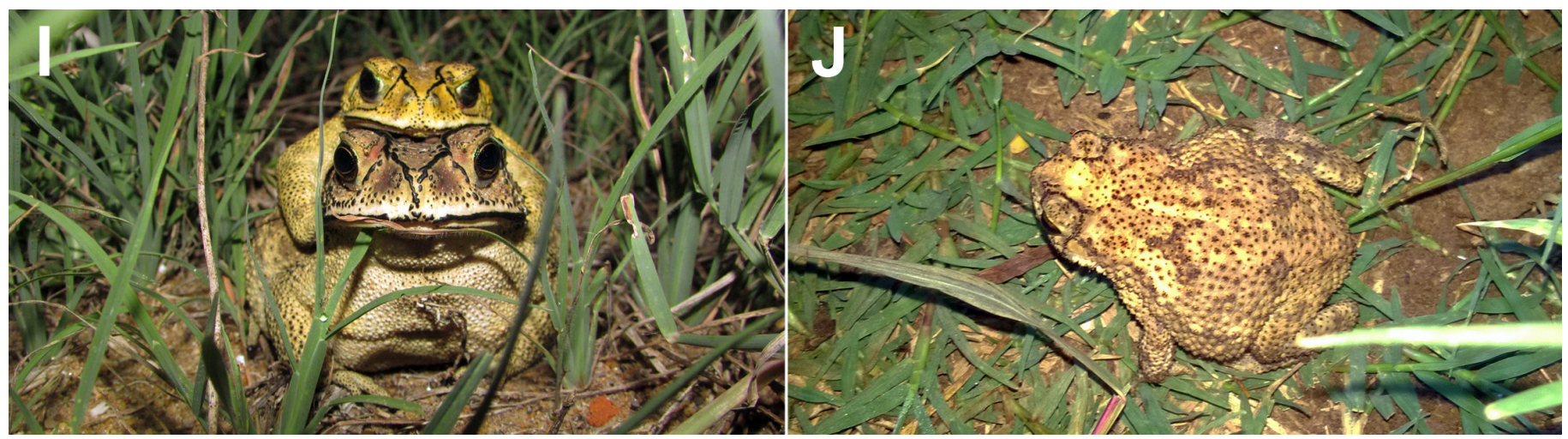

Fig. 6. Amphibians encountered during field surveys at Mannampandal in the Cauvery Delta, Nagapattinam District, Tamil Nadu, India: (I) Asian Common Toad (Duttaphrynus cf. melanosticus) and (J) Schneider's Toad (Duttaphrynus scaber). 


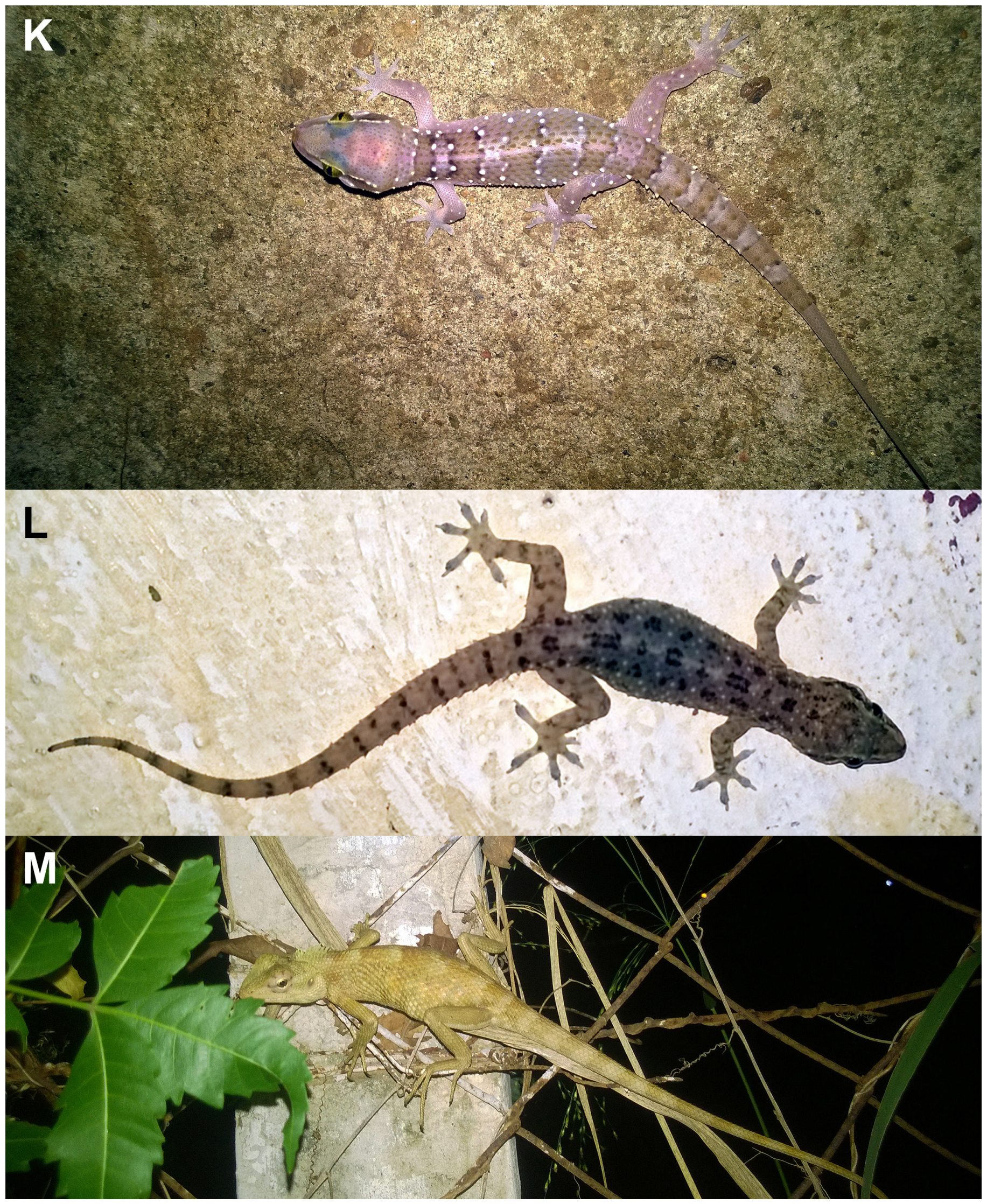

Fig. 7. Reptiles encountered during field surveys at Mannampandal in the Cauvery Delta, Nagapattinam District, Tamil Nadu, India: (K) Blotched House Gecko (Hemidactylus triedrus), (L) Brook's House Gecko (Hemidactylus cf. brookii), and (M) Oriental Garden Lizard (Calotes cf. versicolor). 
low herpetofaunal diversity. The species-rank abundance plot curve that does not reach an asymptotic level indicates that further sampling is needed. The Cauvery Delta region supports a dense human population and is largely devoted to agriculture. The anthropogenic pressure results in consid- erable contact (and conflict) between snakes and humans, clearly demonstrated by the 53 rescue calls during the study period.

The IUCN Red List categorized 30\% of the species encountered as being of Least Concern, but $55 \%$ have not
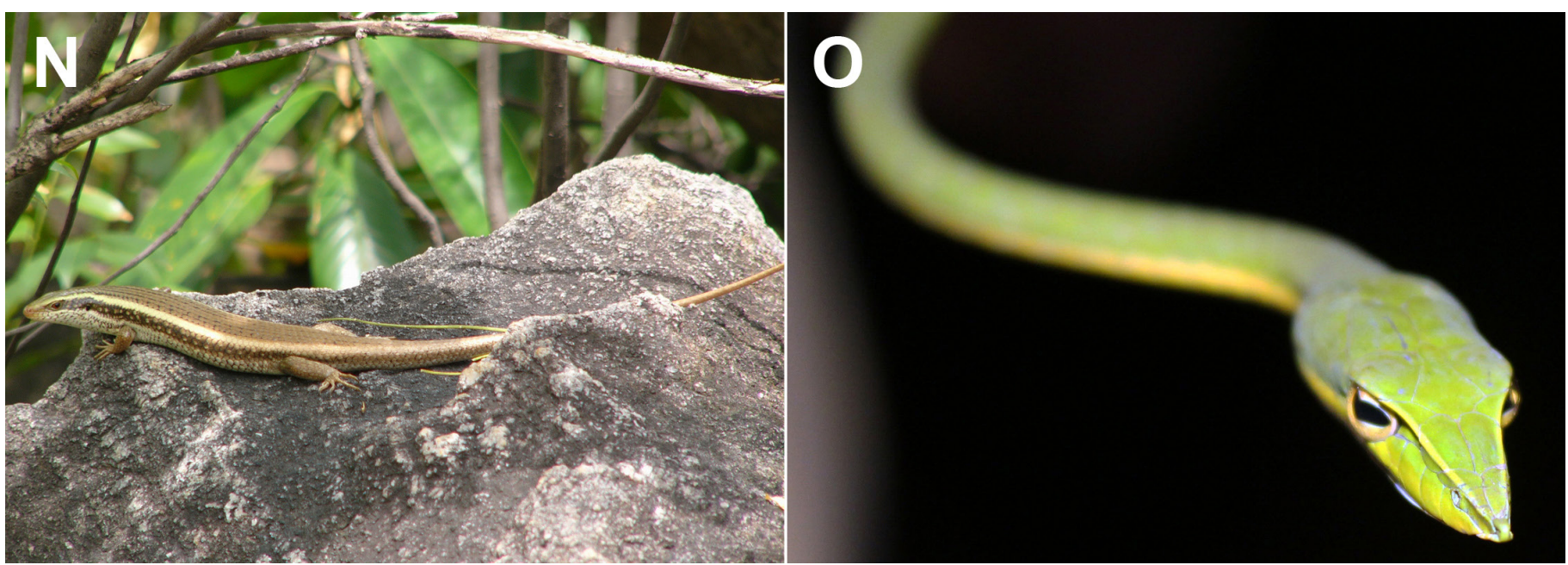

Fig. 8. Reptiles encountered during field surveys at Mannampandal in the Cauvery Delta, Nagapattinam District, Tamil Nadu, India: (N) Keeled Indian Mabuya (Eutropis carinata) and (O) Long-nosed Tree Snake (Ahaetulla cf. nasuta).
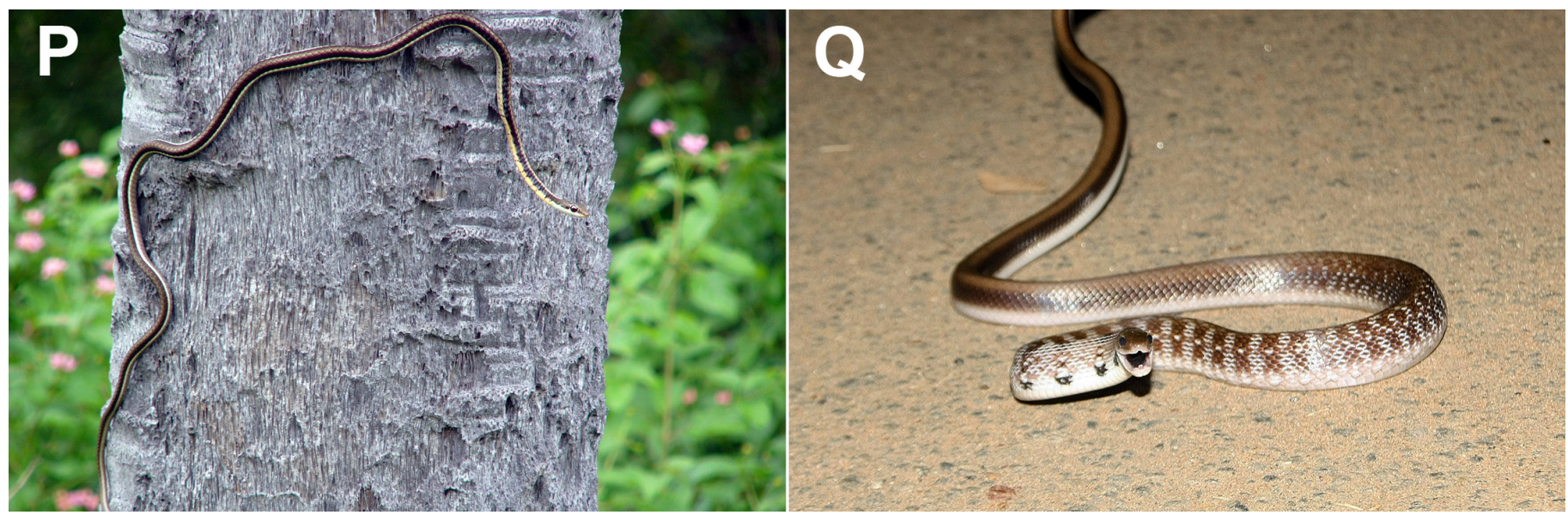

Fig. 9. Reptiles encountered during field surveys at Mannampandal in the Cauvery Delta, Nagapattinam District, Tamil Nadu, India: (P) Common Bronze-backed Tree Snake (Dendrelaphis tristis) and (Q) Trinket Snake (Coelognathus helena).
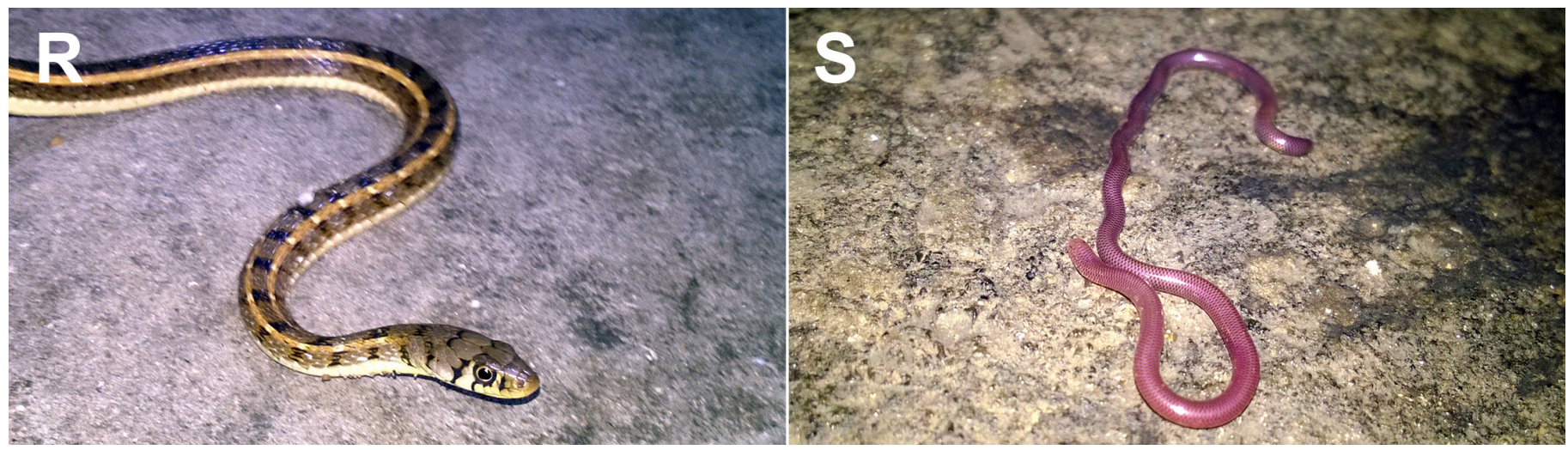

Fig. 10. Reptiles encountered during field surveys at Mannampandal in the Cauvery Delta, Nagapattinam District, Tamil Nadu, India: (R) Buff-striped Keelback (Amphiesma stolatum) and (S) Brahminy Blindsnake (Indotyphlops braminus). 


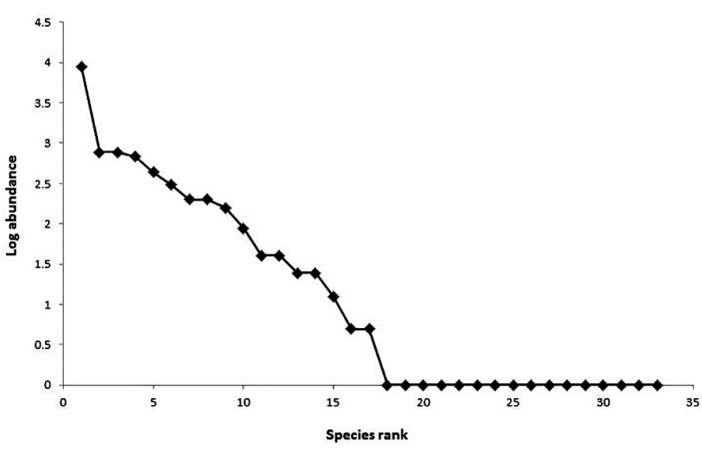

Fig. 11. Rank Abundance Plot for species encountered during field surveys at Mannampandal in the Cauvery Delta, Nagapattinam District, Tamil Nadu, India.

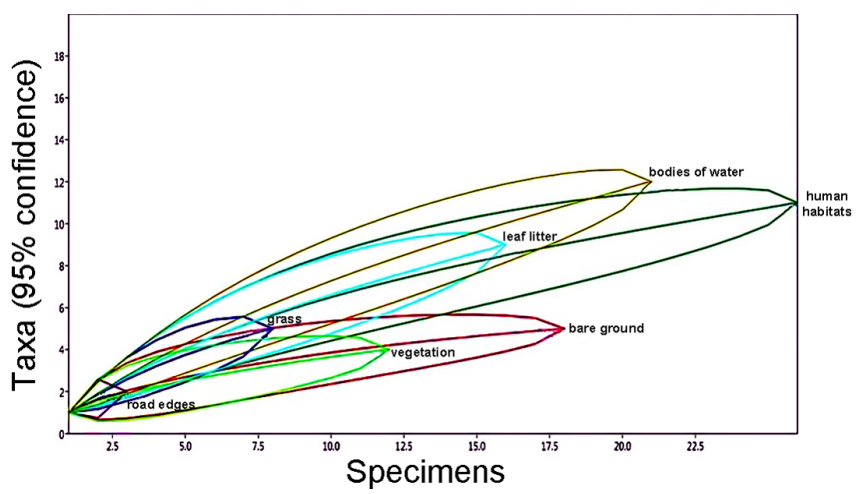

Fig. 12. Individual rarefaction curve with special reference to microhabitats exploited by the herpetofauna at Mannampandal in the Cauvery Delta, Nagapattinam District, Tamil Nadu, India.

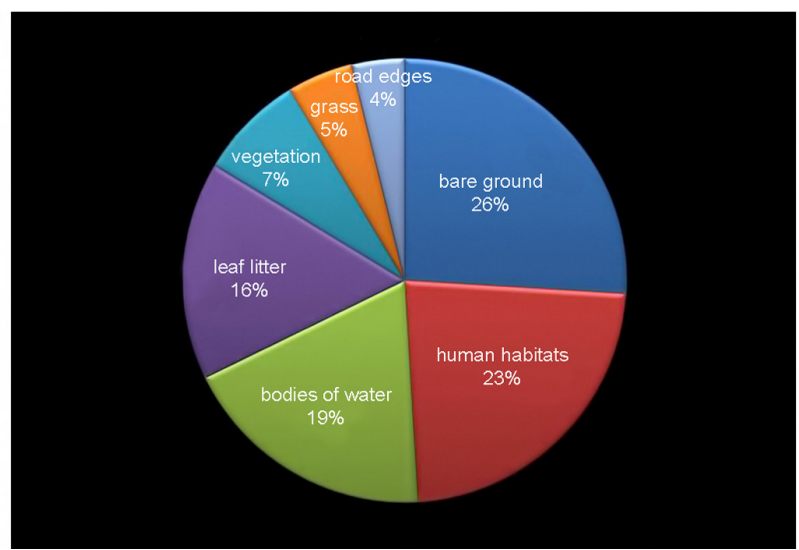

Fig. 13. Microhabitats utilized by the herpetofauna at Mannampandal in the Cauvery Delta, Nagapattinam District, Tamil Nadu, India.

been assessed and will need to be evaluated before we can determine whether any of the species in the area are threatened. Although the principal threats to the herpetofauna of the Cauvery Delta are habitat loss and alterations, a lack of awareness of the herpetofauna and its potential benefits causes most encounters between local residents and especially snakes to result in the death of the latter. Amphibians and reptiles play a number of important functions in both natural and human-altered ecosystems. These include the control of inver-

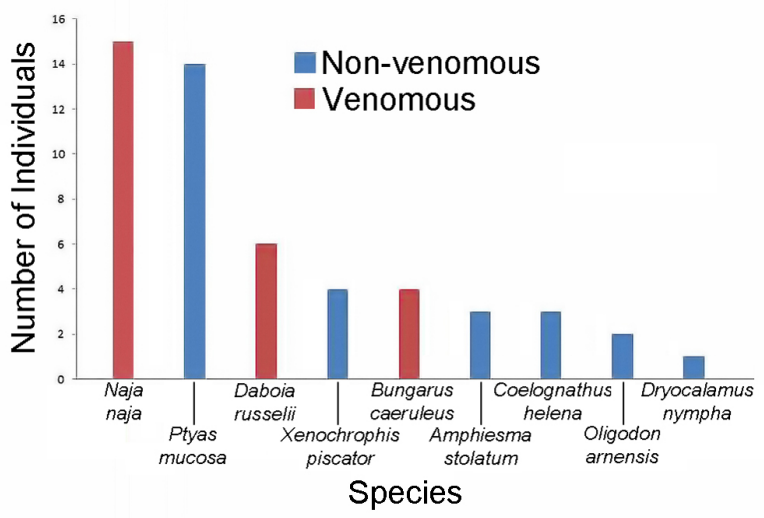

Fig. 14. Species of snakes rescued from local households in Mannampandal, Nagapattinam District, Tamil Nadu, India.

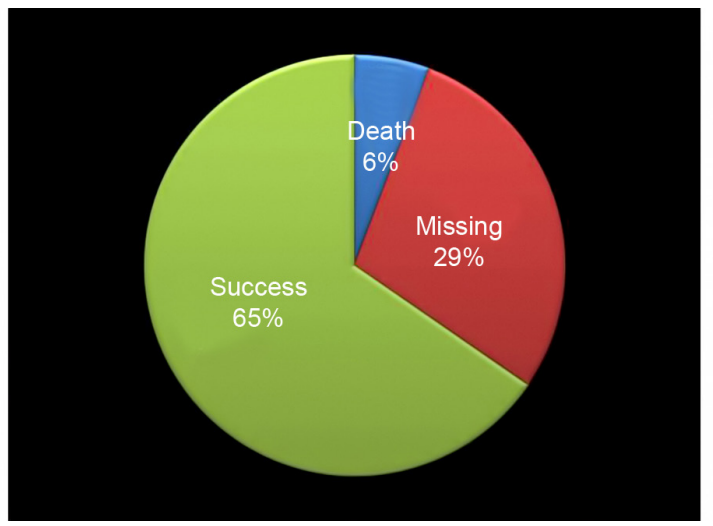

Fig. 15. Results of snake rescues from Manammpandal, Nagapattinam District, Tamil Nadu, India.

tebrate and vertebrate pests, serving as food for other animals, and scavenging on dead and injured animals (Kurniati 2005). Many species are disappearing at alarming rates, often without formal scientific recognition and primarily due to human activities that are likely exacerbated by climate change (Rout et al. 2016). A better understanding of local biotic communities is a small first step in slowing the pace of extinctions.

\section{Acknowledgements}

I thank the Anbhanathapuram Vahaira Charity College (autonomous) and the Department of Wildlife Biology for permission to carry out this study, my friends Sridhar Halali and Dhiraj Halali for comments on an early draft of this manuscript, and my juniors Rubul, Shubasish and Koustaf for assistance in the field and for photographs. I also thank the AVC College security people and the residents of Mannampandal Village for their constant support of my studies. This paper is dedicated to my best friend and wildlife biologist, the late Mr. Prasanth Ettopina.

\section{Literature Cited}

Aengals, R., V.M. Sathishkumar, and Palot, M.J. 2011. Updated Checklist of Indian Reptiles. Zoological Survey of India, Kolkata. <http://zsi.gov.in/ 
WriteReadData/userfiles/file/Checklist/Checklist\%20of\%20Indian\%20 Reptiles.pdf>.

Ali, A.M.S., S. Asokan, R. Manikannan, and P. Radhakrishnan. 2011. Checklist and nesting patterns of avifauna in and around Mayiladuthurai region, Tamil Nadu, India. Journal of Threatened Taxa 3: 1842-1850.

Dinesh, K.P., C. Radhakrishnan, and U.N. Kulkarni. 2015. Checklist Amphibians of India. Mhadei Research Center, Belgaum, India. <http://mhadeiresearchcenter.org/resources/>.

Dinesh, K.P., C. Radhakrishnan, K.V. Gururaja, K. Deuti, and G. Bhatta. 2013. A Checklist of Amphibia of India with IUCN Red List Status Zoological Survey of India, Kolkata. < http://indiabiodiversity.org/biodiv/content/documents/ document-8e24da1a-e893-4400-9d35-b2f80d1231d5/381.pdf>.

Daniel, J.C. 2002. The Book of Indian Reptiles and Amphibians. Oxford University Press and Bombay Natural History Society, Mumbai, India.

Ganesh, S.R. and S.R. Chandramouli. 2007. A study of the herpetofaunal community in Mannampandal, Nagaipattinam Dist., Tamil Nadu. Cobra 1(4): 33-43.

Ganesh, S.R. and S.R. Chandramouli, S.R. 2010. Rediscovery of Hemidactylus scabriceps (Anandale, 1906) (Reptilia: Sauria: Gekkonidae) from eastern Tamil Nadu, India. Russian Journal of Herpetology 17: 70-74.

Gururaja, K.V. 2011. A Pocket Guide to the Frogs and Toads of Western Ghats. Gubbi Labs, Bangalore, India.
Hammer, Ø. 2017. The past and future of Past, version 3. Submitted.

Heyer, W.R., M.A. Donnelly, R.W. McDiarmid, L.-A.C. Hayek, and M.S. Foster (eds.). 1994. Measuring and Monitoring Biological Diversity: Standard Methods for Amphibians. Smithsonian Institution Press, Washington, DC.

Kurniati, H. 2005. Species richness and habitat preferences of herpetofauna in Gunung Halimun National Park, West Java. Berita Biologi 7: 263-271.

Meyers, N., R.A. Mittermeier, C.G. Mittermeier, G.A.B. da Fonseca, and J. Kent. 2000. Biodiversity hotspot for conservation priorities. Nature 403: 853-858.

Nath, A., S. Sutradhar, A. Kalaimani, V. Vijyan, Krishna Kumar, B. Laxmi Narayana, B. Naresh, G. Baburao, S. Dharwadkar, Gokul Krishnan, B.Vinoth, R. Maniraj, D. Mahendra Reddy, D. Adi Mallaiah, and K. Swamy. 2012. Herpetofaunal assemblage with special emphasis on community structure and spatiality in amphibians of Cauvery delta region, Tamil Nadu. Asian Journal of Conservation Biology 1(2): 78-85.

Rout, S., B. Baruah, N. Mishra, and T. Panda. 2015. Diversity of herpetofaunal community in Kundalika wildlife sanctuary, Odisha, India. Current Life Sciences 2: 9-14.

Smith, M.A. 1935. Fauna of British India including Ceylon and Burma. Reptilia and Amphibia. Vol. II.-Sauria. Taylor \& Francis, London, UK.

Whitaker, R. and A. Captain. 2004. Snakes of India, The Field Guide. Draco Books, Chennai, India. 